\title{
Environment agency plans come under fire
}

London. The British government has rejected concerns that the proposed merger of three important public watchdogs into a single environment agency is a hasty measure and potentially harmful to science.

The merger, under the Environment Bill being piloted through Parliament, of the National Rivers Authority (NRA), Her Majesty's Inspectorate of Pollution (HMIP) and Britain's waste regulation authorities into a single Environment Agency from April 1996, is vital in developing a "holistic" approach to environmental problems, according to Environment Secretary John Gummer. The merger is designed to introduce cost-benefit analysis to environmental regulations. It will "engender a cultural change whereby environmental decision making will cease to be considered as an optional and costly extra duty", he says.

The government's critics, however, are far from satisfied with Mr Gummer's reassurances and are seeking rapid answers to several key questions. The rhetoric of an 'integrated approach to solving environmental problems' has yet to be matched with workable proposals, according to David Coates, head of commercial affairs at the Natural Environment Research Council's Centre for Ecology and Hydrology. The government, he adds, must also clear up the present confusion over who will fund the new agency.

The government has promised $£ 5$ million in the agency's start-up costs. But it has so far refused to say who will fund the agency full-time. "A move to a multidisciplinary, holistic approach will need substantial investment in a programme for strategic research and development," says Coates. Yet up to now, "there has been no satisfactory answers as to where that investment will come from".

Industry is expected to foot some of the bill. But representatives, while agreeing investment is needed to enable the agency to maintain credibility, do not see themselves fulfiling this role. Michael La Graff, general manager of health and safety at BP Chemicals, says industry should pay no more than "its fair share of environment protection costs and of the costs of the agencies".

Other fears yet to be allayed include concerns that the new agency will promote applied research at the expense of basic research. However Mervyn Bramley, head of research and development at NRA, says the individual agencies, when merged, will become a source of formidable research expertise.

"From the very first day the agency exists, it will draw on the scientific understanding that is the product of this cooperation [between the NRA and the HMIP and waste regulatory authorities], and the research the NRA has done over the past five years. The R\&D work we are carrying out now will be crucial for sound environmental decisionmaking for the future." Fiona Gammie

\section{Radiation study moves unsettle Japanese researchers}

Tokyo. Officials of the US Department of Energy (DoE) visited Japan last week to try to calm the uproar generated by the department's plans to reorganize management of a joint US-Japan research foundation that has been studying the effects of radiation on atomic bomb victims for nearly 50 years.

This follows a letter sent by leading radiation biologists from the Universities of Tokyo, Kyoto and Hiroshima, as well as Nara Medical University, to Hazel O'Leary, US Energy Secretary, expressing concern about the DoE's plans.

The letter points out in particular that DoE is said to be planning to use the Radiation Effects Research Foundation (RERF), based in Hiroshima, as part of a training programme for the environmental cleanup of nuclear waste; it warns that this could hinder RERF's ability to continue its present long-term studies and damage the perceived neutrality and peaceful purpose of the programme.

In January, the department caused dismay among radiation biologists in both Japan and the United States by announcing plans to change the organization responsible for management of US participation in the foundation (see Nature 106, 374; 1995).

From its inception in 1947, the joint programme has been run on the US side by the National Academy of Sciences (NAS), and the academy's involvement has helped to win respect for the programme around the world. DoE now wants to transfer management of the programme to a US university or group of universities in order to attract young US scientists into research in radiation biology. But both Japanese and US sci- entists associated with RERF fear this could jeopardize the programme in several ways.

Japanese scientists have been uncharacteristically outspoken in their criticism of the US move. In their letter to O'Leary, sent on 14 March, they echo comments of RERF

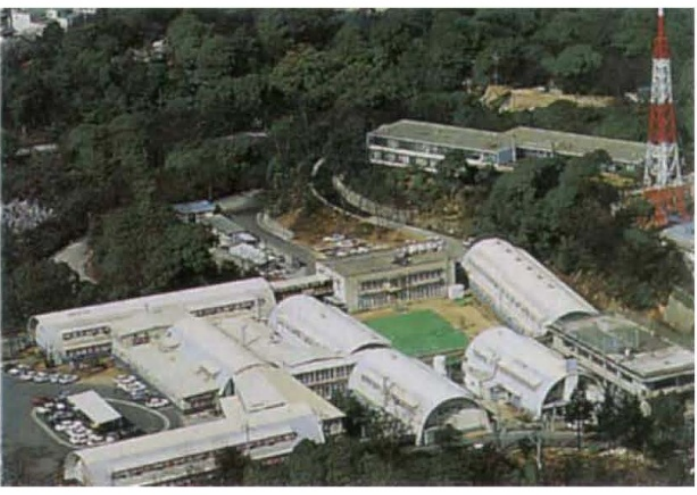

RERF: US plans 'could threaten its neutral position'. scientists, saying that NAS acts as a "buffer" between DoE and RERF and provides "scientific credibility and cooperation of Abomb victims essential to future RERF accomplishments".

Steven Galson, DoE's chief medical officer for environment, safety and health, who led last week's delegation to Japan, says there have been many "misconceptions" and admits that the announcement of the changes by DoE in January "could have been handled much better". But he insists the new arrangements will not impinge on the autonomy and neutrality of RERF, and that a university or group of universities can act as a "buffer" between DoE and RERF in the same way as the academy does now.

Despite reports circulating in Washington, Galson claims that there will be no direct link between the training of young US scientists at RERF and the weapons cleanup programmes, although the results of RERF studies may well be applied in setting safety standards for the clean-up.

Another concern of RERF scientists is that DoE plans to ask the new administrative organization to evaluate the scientific objectives of the programme and make recommendations for its future in line with DoE objectives. This concern arises from an unsolicited proposal for management of the programme, sent to DoE by Columbia University in New York, which calls for such evaluation independently of RERF's own binational scientific council.

Galson says a Request for Proposals (RFP) for managing the programme will be announced in about a month. But it remains "unsettled" whether the RFP will include a component for evaluation or not. He says he will, however, convey to Washington the strong objections of RERF scientists to such evaluation. Under the RERF charter, according to DoE officials, a binational group of scientific advisers is responsible for the foundation's scientific programme, and this will not change.

Japan's Ministry of Health and Welfare, which administers the Japanese side of the programme, has said little on the issue. According to Galson, the ministry maintains a "neutral" stance and accepts that it is up to DoE to make arrangements for US management of the programme. David Swinbanks 